\title{
Effects of common carp (Cyprinus carpio) on water quality in aquatic ecosystems dominated by submerged plants: a mesocosm study
}

\author{
Xiaochang Qiu ${ }^{1, a}$, Xueying Mei ${ }^{2, a}$, Vladimir Razlutskij ${ }^{3}$, Lars G. Rudstam ${ }^{4}$, Zhengwen Liu ${ }^{1,5}$, \\ Chunfu Tong ${ }^{6}$ and Xiufeng Zhang ${ }^{1, *}$ \\ ${ }^{1}$ Department of Ecology and Institute of Hydrobiology, Jinan University, Guangzhou, 510632, Pr China \\ ${ }^{2}$ College of Resources and Environment, Anhui Agricultural University, Hefei, 230036, Pr China \\ ${ }^{3}$ State Scientific and Production Amalgamation Scientific-practical center of the National Academy of Sciences of Belarus for biological \\ resources, Minsk, Belarus \\ ${ }^{4}$ Cornell Biological Field Station, Department of Natural Resources, Cornell University, New York, USA \\ ${ }^{5}$ State Key Laboratory of Lake Science and Environment, Institute of Geography and Limnology, Chinese Academy of Sciences, \\ Nanjing, 210008, Pr China \\ ${ }^{6}$ State Key Laboratory of Estuarine and Coastal Research, East China Normal University, Shanghai, 200062, Pr China
}

Received: 18 January 2019 / Accepted: 28 April 2019

\begin{abstract}
Common carp (Cyprinus carpio) have been introduced into aquatic systems across the world, where their benthivorous feeding behavior has resulted in serious water quality problems. A 12-week mesocosm experiment was set up to test the hypotheses that common carp increase water column nutrient levels and decrease water clarity in aquatic ecosystems dominated by submerged plants. Further, we tested whether the effect of common carp on macrophytes depended on the species of plants. Relative to the controls, the presence of carp decreased water clarity by increasing total suspended solids (TSS) and light attenuation. However, levels of total nitrogen (TN) and total phosphorus (TP) in the water column were reduced. No significant change in phytoplankton biomass (measured as chlorophyll $a$ ) and the biomass of Hydrilla verticillata was observed between common carp treatment mesocosms and controls, but the common carp did reduce the biomass of the submerged macrophyte Vallisneria denseserrulata. We conclude that removal of common carp is likely to improve water clarity in aquatic ecosystems dominated by submerged plants primarily by decreasing TSS and that the effect of common carp on macrophytes is stronger for the meadow forming Vallisneria than for the canopy forming Hydrilla.
\end{abstract}

Keywords: common carp / submerged plants / aquatic ecosystem / water quality / water clarity

Résumé - Effets de la carpe commune (Cyprinus carpio) sur la qualité de l'eau dans les écosystèmes aquatiques dominés par les plantes submergées: une étude en mésocosme. La carpe commune (Cyprinus carpio) a été introduite dans les écosystèmes aquatiques du monde entier, où son comportement alimentaire benthivore a entraîné de graves problèmes de qualité de l'eau. Une expérience en mésocosme d'une durée de 12 semaines a été mise sur pied pour vérifier les hypothèses selon lesquelles la carpe commune augmente les niveaux de nutriments dans la colonne d'eau et diminue la clarté de l'eau dans les écosystèmes aquatiques dominés par des plantes submergées. De plus, nous avons vérifié si l'effet de la carpe commune sur les macrophytes dépendait de l'espèce des plantes. Par rapport aux témoins, la présence de carpes a réduit la clarté de l'eau en augmentant la quantité de solides en suspension (TSS) et l'atténuation de la lumière. Cependant, les niveaux d'azote total (TN) et de phosphore total (TP) dans la colonne d'eau ont été réduits. Aucun changement significatif de la biomasse du phytoplancton (mesurée en chlorophylle $a$ ) et de la biomasse de Hydrilla verticillata n'a été observé entre les mésocosmes expérimentaux avec carpe commune et les témoins, mais la carpe commune a réduit la biomasse du macrophyte immergé Vallisneria

\footnotetext{
*Corresponding author: wetlandxfz@163.com

${ }^{a}$ Both Xiaochang Qiu and Xueying Mei should be treated as the first author.
} 
denseserrulata. Nous concluons que l'élimination de la carpe commune est susceptible d'améliorer la clarté de l'eau dans les écosystèmes aquatiques dominés par les plantes submergées, principalement en diminuant les MES, et que l'effet de la carpe commune sur les macrophytes est plus marqué chez Vallisneria qui forme des «prairies» que chez Hydrilla qui forme les couverts.

Mots clés : carpe commune / plantes submergées / écosystème aquatique / qualité de l'eau / clarté de l'eau

\section{Introduction}

The common carp, Cyprinus carpio, has been introduced into aquatic systems world-wide. Its broad environmental tolerances (Horoszewicz, 1973; Crivelli, 1981), high fecundity and long lifespan (Fischer et al., 2013) combine to make common carp a highly invasive species (Roberts et al., 1995). The wide distribution of common carp and the species' role as an ecosystem engineer makes common carp one of the more important species in freshwater systems (Parkos et al., 2003; Semenchenko et al., 2017) affecting water quality and submerged vegetation.

Common carp is benthivorous and forage by disturbing as much as the top $20 \mathrm{~cm}$ of lake sediment (Huser et al., 2016). This activity exerts substantial effects on ecosystem structure and function (Kaemingk et al., 2017), resuspending particulate matter and potentially releasing nutrients sequestered in the sediment into the water column. This resuspension of sediment by common carp is known to increase turbidity, although this is not always observed. Fletcher et al. (1985) found that the presence of carp did not increase water turbidity, whereas Chumchal et al. (2005) concluded turbidity increased along with chlorophyll $a$ and total phosphorus (TP) levels in systems with common carp. Bajer and Sorensen (2015) implicated common carp reduced water clarity and damaged the macrophyte communities, but recorded no apparent effect on TP. Fischer et al. (2013) suggested that common carp reduced water clarity, increased nutrient concentrations and reduced macrophyte biomass. Additional nutrients excreted by the common carp (Roberts et al., 1995) have been shown to stimulate phytoplankton growth (Fischer et al., 2013).

Common carp can suppress submerged plants both indirectly by increasing light attenuation, and directly by uprooting plants during foraging and by consuming plants (King and Hunt, 1967; Crivelli, 1983). Analyses of common carp stomach contents have revealed plant tissues, seeds and detritus (Crivelli, 1981; Hinojosa-Garro and Zambrano, 2004). Bajer et al. (2009) demonstrated that common carp caused losses of vegetation over large areas for at least 4 years, damaging the ecological integrity of a shallow lake.

In addition, common carp can also affect the composition of submerged plant communities (Miller and Crowl, 2006) by feeding selectively on plants with higher food values. The experiment of Roberts et al. (1995) showed that common carp can exert a direct effect on Vallisneria sp. and Chara jibrosa, eliminating them from some systems, while no change was recorded in the abundances of Juncus ingens, Schoenoplectus validus or Myriophyllum papillasum. Miller and Crowl (2006) found that Ceratophyllum demersum and Scirpus validus were also significantly reduced by common carp, whereas Potamogeton pectinatus was unaffected. Common carp were also observed to consume more Chara aspera than other macrophytes, such as Typha latifolia, C. demersum and S. validus (Miller and Provenza, 2007).

Submerged plant communities play a central role in the ecological condition and sustainability of freshwater systems, and changes in the abundance and composition of such communities may have significant effects, not least on water quality. In shallow lakes, submerged plants play a key role in suppressing phytoplankton growth (Lemmens et al., 2018) and improving and maintaining water clarity. Any impact of common carp activities is thus likely to be ecologically significant. Although the literature on the effects of common carp on aquatic ecosystems is extensive, more work is still needed to understand effects on water quality, especially in systems dominated by submerged plants. In addition, less is known about how common carp influence macrophytes with different morphology, such as meadow formers (biomass equally distributed over depth, e.g. Vallisneria), and canopy formers (biomass distributed mostly at the top of the plant, e.g. Hydrilla).

Here we present results from a mesocosm experiment conducted to evaluate the effects of common carp on water quality of nutrients, total suspended solid (TSS) concentrations, light intensity, and submerged plant biomass. We hypothesized that common carp would have a negative impact on water quality by increasing nutrient levels in the water column, decreasing water clarity and on submerged plants with the impact more stronger for Vallisneria than for Hydrilla. The results of this study may inform lake managers interested in reducing or removing benthivorous fish to improve water quality of aquatic ecosystem.

\section{Materials and methods}

\subsection{Experimental mesocosm set up}

The mesocosm experiments were carried out in seven tanks $($ diameter $=1.2 \mathrm{~m}$, height $=1.2 \mathrm{~m})$ containing sediment, water, and plants. Sediment was obtained from Ming Lake, a eutrophic shallow water body in Guangzhou City. The sediment was air-dried, powered, and sieved through a stainless sieve (mesh size, $0.5 \mathrm{~mm}$ ) to remove coarse debris (Zhang et al., 2016). The homogenized sediment was added as a $10 \mathrm{~cm}$ thick layer in each mesocosm (Zhang et al., 2016). We planted 30 individuals each of two species of submerged macrophytes evenly in the mesocosm: the meadow forming Vallisneria denseserrulata and the canopy forming Hydrilla verticillata. All plants originated from Huizhou West Lake in Huizhou, Guangdong Province and cultivated in Jinan University for several years. The $V$. denseserrulata and $H$. verticillata were washed with distilled water to remove periphyton and debris before planting. Before planting, 10 plants of each species were randomly selected and washed through a $1 \mathrm{~mm}$ mesh sieve and oven-dried at $80^{\circ} \mathrm{C}$ to 
constant weight to determine the dry weight of the plants. Each $V$. denseserrulata plant was $30 \mathrm{~cm}$ in length with dry weights of $0.73 \pm 0.19 \mathrm{~g}$. For Hydrilla verticillata, we used apical shoots separated from their mother plants, each $30 \mathrm{~cm}$ in length with dry weights of $0.04 \pm 0.01 \mathrm{~g}$ (Zhang and Liu, 2011). The biomass of $V$. denseserrulata and $H$. verticillata in each mesocosm at the beginning of the experiment were therefore $21.8 \pm 5.8 \mathrm{~g}$ and $1.3 \pm 0.2 \mathrm{~g}$ respectively.

The mesocosms were each filled to a depth of $1.0 \mathrm{~m}$ with rainwater $\left(\mathrm{TN}=0.94 \mathrm{mg} \mathrm{L}^{-1}, \mathrm{TP}=0.01 \mathrm{mg} \mathrm{L}^{-1}\right)$ and allowed to equilibrate exposed to natural sunlight for seven weeks, after which nutrient concentrations of the water in the mesocoms were $0.63 \pm 0.06 \mathrm{mg} \mathrm{L}^{-1} \mathrm{TN}$ and $0.03 \pm 0.01 \mathrm{mg} \mathrm{L}^{-1} \mathrm{TP}$.

Common carp bought from the market in Guangzhou City were habituated in $100 \mathrm{~L}$ tanks for two weeks before being introduced to the mesocosms. Two individuals $(16.4 \pm 1.5 \mathrm{~cm}$ in length and $63.8 \pm 9.1 \mathrm{~g}$ in wet weight) were added to each of three mesocosms as common carp treatments. Another four mesocosms were maintained as no fish controls. The experiment ran for 12 weeks from June to September, 2017, during which time nitrogen $(\mathrm{N})$ in the form of $\mathrm{KNO}_{3}$ and phosphorus (P) as $\mathrm{NaH}_{2} \mathrm{PO}_{4}$ were added to each mesocosm at a rate of $1.5 \mathrm{mg} \mathrm{N} \mathrm{L}^{-1} \mathrm{wk}^{-1}$ and $0.1 \mathrm{mg} \mathrm{P} \mathrm{L}^{-1} \mathrm{wk}^{-1}$, respectively, to mimic external nutrient loading (Zhang et al., 2014). Sampling took place biweekly, with nutrient addition taking place immediately after samples were taken (Zhang et al., 2016). The mesocosms were exposed to natural environmental conditions throughout the experiment.

At the end of the experiment, submerged plants were harvested from each tank, separated according to species and washed with distilled water to remove sediment, debris and attachments. Finally, the plants were oven-dried at $80^{\circ} \mathrm{C}$ to constant weight for about $24 \mathrm{~h}$, and their dry biomasses recorded.

\subsection{Sampling and analysis}

Water samples $(1 \mathrm{~L})$ were collected from $30 \mathrm{~cm}$ below the surface in each mesocosm every two weeks for measurement of total nitrogen (TN), total phosphorus (TP), phytoplankton biomass as chlorophyll $a$ (chl $a$ ), and total suspended solids (TSS). TN was determined by alkaline potassium persulfate UV spectrophotometry (APHA, 1998). TP was determined by ammonium molybdate UV spectrophotometry (APHA, 1998). Chl $a$ was determined by acetone extraction UV spectrophotometry (Jespersen and Christolfersen, 1987). TSS was calculated by weighing filters dried at $108^{\circ} \mathrm{C}$ for $2 \mathrm{~h}$. Light intensity was measured biweekly between $10 \mathrm{a} . \mathrm{m}$. and noon, before water sampling, using an underwater irradiance meter (ZDS-10W) at 1.0 meter below the surface of the water.

\subsection{Statistical analyses}

Repeated measures analyses of variance (RM-ANOVAs) were conducted to analyze differences of treatment effect in these indexes and with time as repeated factor of time effect. Independent sample $t$-test was used to analyze differences in levels of TN and TP, chl $a$, TSS, light intensity on each sampling occasion and to test for difference in macrophyte biomasses between carp treatments and controls at the end of the experiment. All data were analyzed using SPSS 18.0. All results are presented as mean $\pm 1 \mathrm{SD}$.

\section{Results}

\subsection{Nutrients}

Concentrations of $\mathrm{NO}_{3}-\mathrm{N}$ (RM-ANOVAs, treatment effect, $\left.F_{1,10}=64.0, p<0.001\right)$, TN $\left(F_{1,10}=42.8, p=0.001\right)$ and TP $\left(F_{1,10}=9.7, p=0.026\right)$, but not $\mathrm{NH}_{4}{ }^{+}-\mathrm{N}\left(F_{1,10}=0.97\right.$, $p=0.370$ ) (Fig. 1) were lower in common carp treatments than in the controls. Concentrations of $\mathrm{TN}$ and $\mathrm{TP}$ varied significantly over time (RM-ANOVAs, time effect, $F_{5,35}=4.2, p=0.006$ and $F_{5,35}=5.7, p=0.001$, respectively). $\mathrm{NO}_{3}{ }^{-}-\mathrm{N}$ and $\mathrm{TN}$ were lower in the carp treatments than in the controls on each sampling occasion $(t$-test, $p<0.05)$, except on days 70 and 84 for TN. TP was lower in the carp treatment than in the controls on days 42 and 56 ( $t$-test, $p<0.05)$.

\subsection{TSS and phytoplankton}

Concentrations of TSS (Fig. 2) in the common carp treatment were higher than in the controls (RM-ANOVAs, treatment effect, $\left.F_{1,10}=36.6, p=0.002\right)$, while levels of chl $a$, representing phytoplankton abundance, were not (RMANOVAs, treatment effect, $F_{1,10}=2.9, p=0.152$ ), though this parameter was higher on day 28 ( $t$-test, $p<0.05)$. Both TSS and chl $a$ (Fig. 2 ) were seen to vary significantly over time (RM-ANOVAs, time effect, $F_{5,35}=9.6, p<0.001$ and $F_{5, \quad 35}=8.7, p<0.001$, respectively). TSS concentrations were higher in the common carp treatment than that in the controls on every sampling occasion except day 84 ( $t$-test, $p<0.05)$.

\subsection{Light intensity}

The light intensity (Fig. 3) at 1.0 meter below the water surface of the common carp treatment was lower than in the controls (RM-ANOVAs, treatment effect, $F_{1,}{ }_{8}=18.1$, $p=0.008$ ) and varied significantly over time (RM-ANOVAs, time effect, $F_{4,24}=41.7, p=0.024$ ).

On each sampling occasion, light intensity was lower in the common carp treatment than in the controls ( $t$-test, $p<0.05)$, except on day $84(p>0.05)$, indicating that the presence of fish increased light attenuation.

\subsection{Biomass of submerged plants}

At the beginning of the experiment, biomass of $H$. verticillata was $1.25 \pm 0.24 \mathrm{~g} / \mathrm{mesocosm}$ (Fig. 4). At the end of the experiment, the biomasses did not differ between common carp treatments $(77 \pm 45 \mathrm{~g} /$ mesocosm) and the controls $(60 \pm 22 \mathrm{~g} / \mathrm{mesocosm})(p>0.05)$. Biomasses of $V$. denseserrulata on the other hand were lower in the common carp treatments than in the controls $(t$-test, $p<0.05)$ at the end of the experiment. Their biomasses decreased from $21.8 \pm 5.8 \mathrm{~g} /$ mesocosm at the beginning of the experiment to $1.7 \pm 0.6 \mathrm{~g} /$ mesocosm at the end of the experiment in the controls, with an even greater loss in the common carp treatments. 

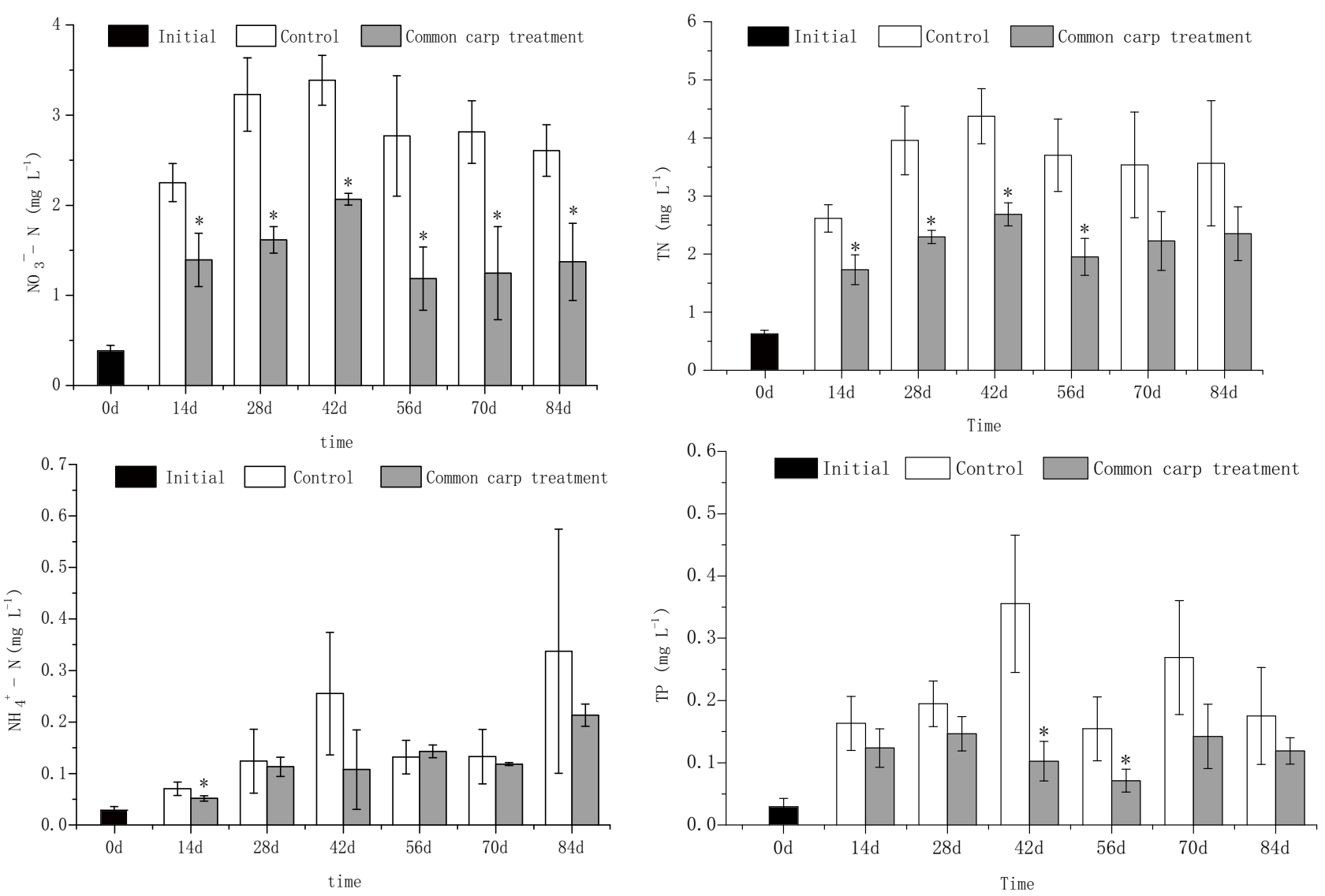

Fig. 1. Nitrogen and phosphorus in different treatments over time. Asterisks indicate significant differences between common carp treatments and the controls $(p<0.05)$. Bars indicate \pm 1 SD.

\section{Discussion}

We found that the presence of common carp was associated with increased TSS concentration and light attenuation. Although we could find no significant relationship between fish presence and increased phytoplankton chl $a$, we did find that the presence of fish appears to reduce the biomass of $V$. denseserrulata. Contrary to our hypothesis, we found no evidence that common carp increase levels of TN and TP, but we did find an association between fish and declining water clarity.

Bioturbation by benthivorous fish can cause resuspension of sedimented materials (Cline et al., 1994) and increase levels of TSS in the water column (Lougheed et al., 1998; Parkos et al., 2003). This disturbance effect explains the reduced availability of light observed at the sediment surface in the common carp treatments.

Increased light attenuation may have a negative effect on submerged plant growth (Badiou and Goldsborough, 2015), especially for $V$. denseserrulata. This species produces a basal rosette of leaves, but does not form a canopy. The plant therefore depends more on light being available near the sediment for growth and survival. In this study, biomasses of $V$. denseserrulata in the common carp (total dry weight $=0.40$ $\pm 0.69 \mathrm{~g}$ ) were lower than in the controls (total dry weight $=$ $1.70 \pm 0.61 \mathrm{~g}$ ). However, the degree to which this reduced biomass was caused directly by the grazing of fish or indirectly by light limitation linked to fish bioturbation cannot be determined from this study. Elsewhere, common carp have had a negative impact on submerged plants biomass (King and Hunt, 1967; Badiou and Goldsborough, 2015).

The apparent lack of a significant effect of common carp on the biomass of $H$. verticillata is consistent with previous work showing that different plant species vary in their susceptibility to the effects of common carp (Zambrano and Hinojosa, 1999). Roberts et al. (1995) reported that common carp can directly consume Vallisneria, preferring it to $H$. verticillata. Also, $H$. verticillata has high rates of reproduction and growth (Shearer et al., 2007), which might compensate for any grazing losses. In addition, more biomass of $H$. verticillata is in a dense canopy distributed near the surface of water and thus less impacted by reduced light condition induced by carp activities. Therefore, the response of an aquatic ecosystem to common carp may be different depending on the dominant submerged plant species present. An aquatic ecosystem that is dominated by $H$. verticillata would be less sensitive to common carp than one dominated by $V$. denseserrulata.

Contrary to our hypotheses, concentrations of TN and TP were lower in mesocosms containing common carp than in the controls. However, most other studies have shown an increase in nutrients with common carp (Breukelaar et al., 1994; Chumchal et al., 2005). There are a couple of explanations for our results. There is a positive relationship between nutrient uptake by the leaves of macrophytes and water velocity, 

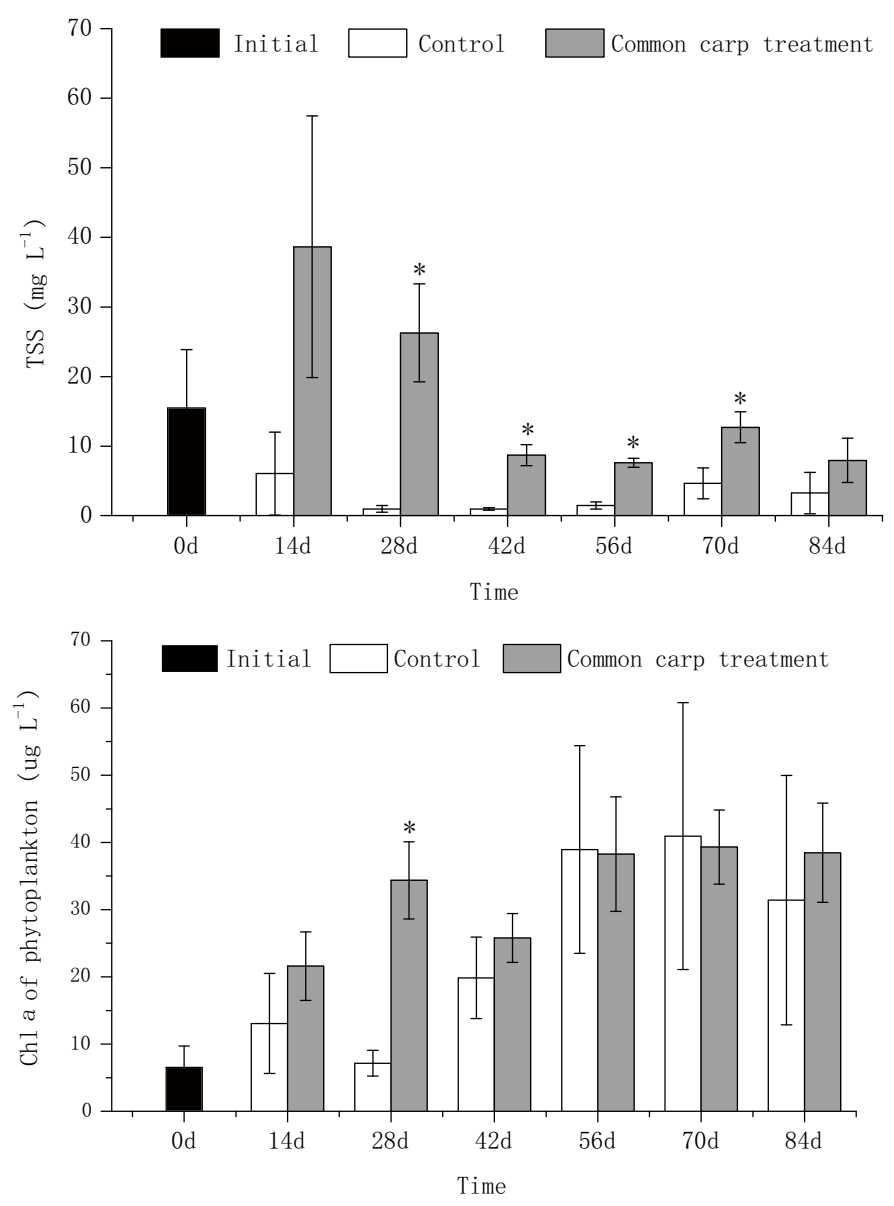

Fig. 2. TSS and chl $a$ of phytoplankton in different treatments over time. Asterisks indicate significant differences between the common carp treatment and the controls $(p<0.05)$. Bars indicate \pm 1 SD.

resulting from reduced thickness of the boundary layer around leaves in disturbed water (Westlake, 1967; Wheeler, 1980; Madsen and Søndergaard, 1983). The swimming of common carp may enhance nutrient uptake by leaves of submerged plants, thereby contributing to decreased nutrient concentrations in the water. In addition, phosphate and dissolved nitrogen in the water can also adsorb to the resuspended sediment particles caused by the fish bioturbation and with these dimentation of these particles carrying it to the bottom. Another explanation is associated with the high plant abundance in our experiments. While foraging activities by common carp can enhance the release of nutrients from sediment, the effect is likely to be mitigated when macrophytes are abundant due to their role in enhancing sedimentation (Qin and Threlkeld, 1990; Cline et al., 1994). Additionally, activities by carp may increase the water exchange between deeper layer and surface layer which may increase oxygen concentrations at the sediment-water interface and thus decreased the sediment $\mathrm{P}$ release by oxidizing the surficial sediments. Whether denitrification is a possible mechanism causing nitrogen loss in our experiments is unknown as we did not measure dissolved oxygen in the surficial sediment. Finally, common carp may also consume some particles suspended in water column, further helping to reduce nutrient

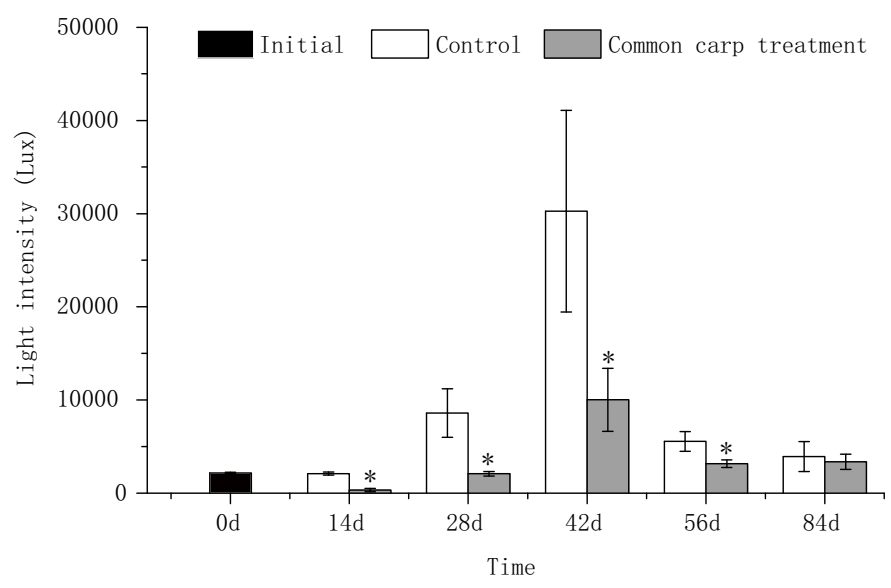

Fig. 3. Light intensity in different treatments over time. Asterisks indicate significant differences between the common carp treatments and the controls $(p<0.05)$. Bars indicate \pm 1 SD.

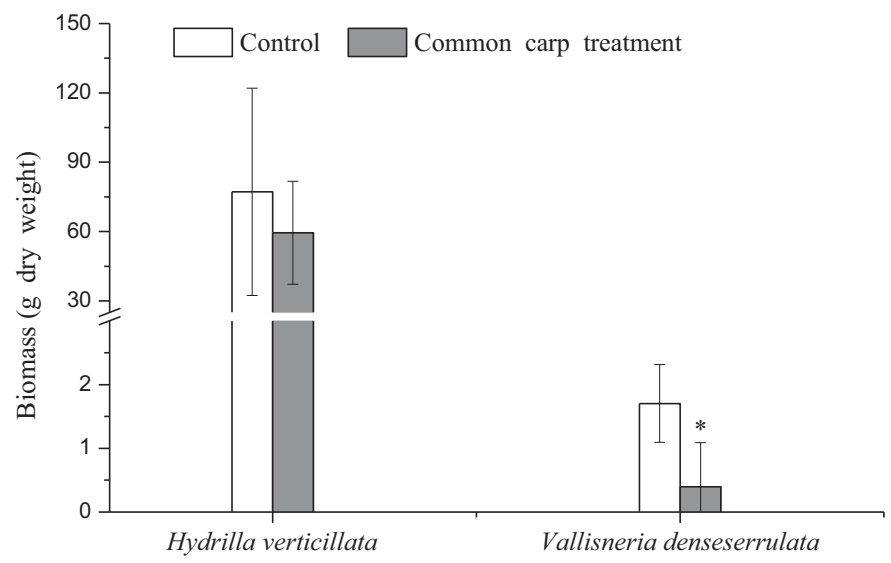

Fig. 4. Submerged plant biomass in different treatments. Asterisk indicates a significant difference between the common carp treatment and the controls $(p<0.05)$. Bars indicate \pm 1 SD.

levels (Boers et al., 1991; Roberts et al., 1995). Note that in this experiment we added nutrients to mimic external nutrient loading. The concentrations of $\mathrm{TN}$ and $\mathrm{TP}$ might have increased due to the bioturbation of the fish if no nutrients were added during the experiment simulating a system without external loading. However, a system without nutrient additions may not reflect a real lake.

The effect of common carp on phytoplankton is more variable. Previous studies have demonstrated that common carp have positive effects on the growth and biomass of phytoplankton (Breukelaar et al., 1994; Roberts et al., 1995). However, Fischer et al. (2013) was not able to observe any increase in chl $a$ in treatments with common carp present and Lougheed et al. (1998) found no significant correlation between chl $a$ concentration and common carp biomass. Likewise in this study, we found no significant difference in chl $a$ between common carp treatment and controls, possibly because of the high abundance of macrophytes (density $=61.5 \mathrm{gm}^{-2}$ ) limiting phytoplankton growth in both treatments. 
In conclusion, in ecosystems dominated by submerged plants, common carp can negatively impact water clarity by increasing TSS concentration which increase light attenuation in the water column. However, contrary to our expectations, common carp presence reduced the concentrations of TN and $\mathrm{TP}$ and had no significant impact on phytoplankton biomass (chlorophyll $a$ ). The fish can also reduce the biomass of $V$. natans but not $H$. verticillata, which has important implications for plant management. By planting carp-resistant or carptolerant plants we can minimize their impact because decline of submerged plants can markedly alter many aspects of aquatic ecosystem. Our findings indicate that the removal of common carp would be a useful practice for managers to protect and maintain water clarity in well-vegetated aquatic ecosystems.

Acknowledgements. We thank the two anonymous reviewers for their constructive editorial comments. This research was supported by the National Natural Science Foundation of China (No.41771100; 41811530056); the Natural Science Foundation (No. 1608085MD85) and the Key Projects of Education Department (No. KJ2017A161) of Anhui province, China; and with additional support from the ChineseBelarusian Joint Project of Belarussian Republican Foundation for Fundamental Research (B18KI-007).

\section{References}

APHA. 1998. Standard methods for the examination of water and wastewater, 20th ed. Washington: American Public Health Association.

Badiou PHJ, Goldsborough LG. 2015. Ecological impacts of an exotic benthivorous fish, the common carp (Cyprinus carpio L.), on water quality, sedimentation, and submerged macrophyte biomass in wetland mesocosms. Hydrobiologia 755: 107-121.

Bajer PG, Sorensen PW. 2015. Effects of common carp on phosphorus concentrations, water clarity, and vegetation density: A whole system experiment in a thermally stratified lake. Hydrobiologia 746: 303-311.

Bajer PG, Sullivan G, Sorensen PW. 2009. Effects of a rapidly increasing population of common carp on vegetative cover and waterfowl in a recently restored Midwestern shallow lake. Hydrobiologia 632: 235-245.

Boers P, Ballegooijen LV, Uunk J. 1991. Changes in phosphorus cycling in a shallow lake due to food web manipulations. Freshw Biol 25: 9-20.

Breukelaar AW, Lammens EHRR, Klein Breteler JGP, Tátrai I. 1994. Effects of benthivorous bream (Abramis brama) and carp (Cyprinus carpio) on sediment resuspensions and concentrations of nutrients and chlorophyll a. FreshwBiol 32: 113-121.

Crivelli AJ. 1981. The biology of the common carp, Cyprinus carpio L. in the Camargue, southern France. J Fish Biol 18: 271-290.

Crivelli AJ. 1983. The destruction of aquatic vegetation by carp a comparison between Southern France and United States. Hydrobiologia 106: 37-41.

Chumchal MM, Nowlin WH, Drenner RW. 2005. Biomass-dependent effects of common carp on water quality in shallow ponds. Hydrobiologia 545: 271-277.

Cline JM, East TL, Threlkeld ST. 1994. Fish interactions with the sediment-water interface. Hydrobiologia 275/276: 301-311.
Fischer JR, Krogman RM, Quist MC. 2013. Influences of native and non-native benthivorous fishes on aquatic ecosystem degradation. Hydrobiologia 711: 187-199.

Fletcher AR, Morison AK, Hume DJ. 1985. Effects of carp, Cyprinus carpio L., on communities of aquatic vegetation and turbidity of water bodies in the Lower Goulburn River Basin. Aust J Mar Freshw Res 36: 311-327.

Horoszewicz L. 1973. Lethal and 'disturbing' temperatures in some fish species from lakes with normal and artificially elevated temperature. J Fish Biol 5: 165-181.

Hinojosa-Garro D, Zambrano L. 2004. Interactions of common carp (Cyprinus carpio) with benthic cray fish decapods in shallow ponds. Hydrobiologia 515: 115-122.

Huser BJ, Bajer PG, Chizinski CJ, Sorensen PW. 2016. Effects of common carp (Cyprinus carpio) on sediment mixing depth and mobile phosphorus mass in the active sediment layer of a shallow lake. Hydrobiologia 763: 23-33.

Jespersen AM, Christolfersen K. 1987. Measurements of chlorophyll$a$ from phytoplankton using ethanol as extraction solvent. Arch Hydrobiol 109: 445-454.

Kaemingk MA, Jolley JC, Paukert CP, et al. 2017. Common carp disrupt ecosystem structure and function through middle-out effects. Mar Freshw Res 68: 718-731.

King DR, Hunt GS. 1967. Effect of carp on vegetation in a Lake Erie marsh. $J$ Wildl Manag 31: 181-188.

Lemmens P, Declerck SAJ, Tuytens K, Vanderstukken M, Meester LD. 2018. Bottom-up effects on biomass versus top-down effects on identity: A multiple-lake fish community manipulation experiment. Ecosystems 21: 166-177.

Lougheed VL, Crosbie B, Chow-Fraser P. 1998. Predictions on the effect of common carp (Cyprinus carpio) exclusion on water quality, zooplankton, and submergent macrophytes in a Great Lakes wetland. Can J Fish Aquat Sci 55: 1189-1197.

Madsen TV, Søndergaard M. 1983. The effects of current velocity on the photosynthesis of Callitriche Stagnalis Scop. Aquat Bot 15: 187-193.

Miller SA, Crowl TA. 2006. Effects of common carp (Cyprinus carpio) on macrophytes and invertebrate communities in a shallow lake. Freshw Biol 51: 85-94.

Miller SA, Provenza FD. 2007. Mechanisms of resistance of freshwater macrophytes to herbivory by invasive juvenile common carp. Freshw Biol 52: 39-49.

Parkos JJ, Santucci VJ, Wahl DH. 2003. Effects of adult common carp (Cyprinus carpio) on multiple trophic levels in shallow mesocosms. Can J Fish Aquat Sci 60: 182-192.

Qin J, Threlkeld ST. 1990. Experimental comparison of the effects of benthivorous fish and planktivorous fish on plankton community structure. Arch Hydrobiol 119: 121-141.

Roberts J, Chick A, Oswald L, Oswald L, Thompson P. 1995. Effect of carp, Cyprinus carpio L., an exotic benthivorous fish, on aquatic plants and water quality in experimental ponds. Mar Freshw Res 46: $1171-1180$.

Semenchenko VP, Moroz MD, Sysova EA, Lipinskaya TP. 2017. Effects of common carp (Cyprinus carpio) and bream (Abramis brama) on the structure of the littoral community in a mesotrophic lake (Mesocosm Experiments). Contemp Probl Ecol 10: 632-639.

Shearer JF, Grodowitz MJ, McFarland DG. 2007. Nutritional quality of Hydrilla verticillata (L.f.) Royle and its effects on a fungal pathogen Mycoleptodiscus terrestris (Gerd.) Ostazeski. Biol Control 41: 175-183.

Westlake DF. 1967. Some effects of low-velocity currents on the metabolism of aquatic macrophytes. J Exp Bot 18: 187-205. 
X. Qiu et al.: Knowl. Manag. Aquat. Ecosyst. 2019, 420, 28

Wheeler WN. 1980. Effect of boundary layer transport on the fixation of carbon by the giant kelp Macrocystis pyrifera. Mar Biol 56: 103-110. Zambrano L, Hinojosa D. 1999. Direct and indirect effects of carp (Cyprinus carpio L.) on macrophyte and benthic communities in experimental shallow ponds in central Mexico. Hydrobiologia 408/409: 131-138.

Zhang X, Liu Z. 2011. Interspecific competition effects on phosphorus accumulation by Hydrilla verticillata and Vallisneria natans. J Environ Sci 23: 1274-1278.
Zhang X, Liu Z, Jeppesen E, Taylor WD. 2014. Effects of deposit feeding tubificid worms and filter-feeding bivalves on benthic pelagic coupling: Implications for the restoration of eutrophic shallowlakes. Water Res 50: 135-146.

Zhang X, Liu Z, Jeppesen E, Taylor WD, Rudstam LG. 2016. Effects of benthic-feeding common carp and filter-feeding silver carp on benthic-pelagic coupling: Implications for shallow lake management. Ecol Eng 88: 256-264.

Cite this article as: Qiu X, Mei X, Razlutskij V, Rudstam LG, Liu Z, Tong C, Zhang X. 2019. Effects of common carp (Cyprinus carpio) on water quality in aquatic ecosystems dominated by submerged plants: a mesocosm study. Knowl. Manag. Aquat. Ecosyst., $420,28$. 